\title{
The precious drop
}

\author{
Water is a vital resource and as the climate changes so does the hydrological cycle. What this \\ means for water availability (or excess) on the local and regional scale is key for decision makers \\ and communities.
}

The news is filled with stories of precipitation and water extremes, and one such event is the continuing drought in California. The state has experienced years of below average rainfall and as it headed towards its fourth year of drought a State of Emergency was declared back in January. The drought is a result of decreased rainfall combined with a reduced winter snowpack, and associated spring melt. Attribution of individual climate extremes, such as the current California drought, to climate change is difficult. The Bulletin of the American Meteorological Society recently published its latest annual supplement 'Explaining Extreme Events of 2013 from a Climate Perspective', which includes three studies on the California drought $^{1-3}$. These studies don't agree on the contribution of climate change to the drought. Some of the results suggest that global warming has increased the likelihood of atmospheric conditions favourable for drought, in contrast to other findings that indicate that internal variability of the climate system, such as anomalous sea surface temperatures, is responsible.

\section{It is impossible to separate hydrology into different sections without acknowledging the impact that decisions on one will have on the other sections.}

Although climate change may not be known to be the culprit at this time, it is clear that this event has dried the state and put an increased reliance on groundwater as surface reserves have been depleted. Groundwater is a vital but undermanaged resource (see Commentary by James Famiglietti on page 945). Even though the State of Emergency was declared in January, it took until September for Edmund G. Brown Jr, Governor of California, to sign legislation for groundwater management of the state - the bill aims for the sustainable management of groundwater at the local

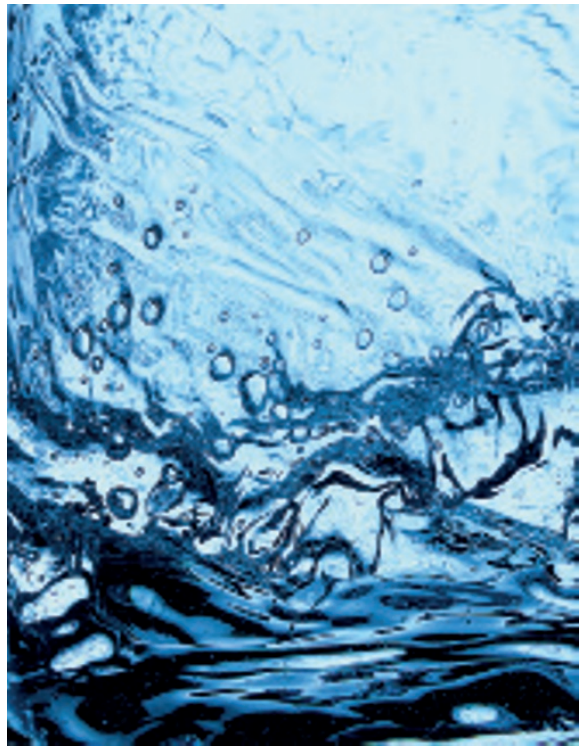

and regional scale ${ }^{4}$ and is the first such bill for the state. It prioritizes groundwater basins that are currently being overextracted, and defines a timeline for management strategies to be in place. This is an important step in sustainability of water resources and their agricultural and industrial use in California.

Management of water is needed to help communities through the current situation - with larger populations, there is greater water demand, so every drop needs to be accounted for and used wisely. It is uncertain when the drought will end projections are for it to persist (or worsen) over most of California until the end of the year ${ }^{5}$ - with many people hoping for a change in natural climate cycles, such as a return of El Niño, the warm phase of the El Niño/Southern Oscilliation, to provide relief. El Niño events bring rains to the eastern Pacific Ocean and western United States, due to increased sea surface temperatures raising atmospheric temperature and rising humid air. The current forecast is $60-65 \%$ chance of an El Niño event beginning later this year ${ }^{6}$, however, this would be unlikely to relieve the severe drought in California as only a weak event is predicted. Climate change means we may never return to the previous normal state so we need to prepare for the new normal.

Groundwater depletion also impacts on surface water, as Famiglietti highlights on page 945 we need to consider the groundwater and surface water as one entity. It is impossible to separate hydrology into different sections without acknowledging the impact that decisions on one will have on the other sections. Management needs to be international as water does not recognize borders, and in some cases it is the border. Shlomi Dinar comments on river basins that are international boundaries in a News and Views article on page 955. Change in territory is a contentious issue and climate change is impacting on the 276 river basins, across 148 countries, forming those boundaries, which could multiply social and political issues. As a recent report from the Pentagon emphasizes climate change is a "threat multiplier", which we are already seeing the effects of ${ }^{7}$. Questions need to be asked now so the problems can be dealt with before they arise or escalate.

Humans have a long history of managing water resources, with one example being the Dujiangyan water network on the Minjiang River, China, built in 256 вс but still in operation today (see News Feature, page 949). Climate change and associated changes in precipitation, temporally and spatially, mean that we need to rethink and adapt management strategies (and be flexible looking forward) to ensure sustainability, water security and political stability.

\section{References}

1. Swain, D. L. et al. Bull. Am. Meteor. Soc. 95 (Explaining Extreme Events of 2013 from a Climate Perspective special supplement), S3-S7 (2014).

2. Wang, H. \& Schubert, S. Bull. Am. Meteor. Soc. 95 (Explaining Extreme Events of 2013 from a Climate Perspective special supplement), S7-S11 (2014).

3. Funk, C., Hoell, A. \& Stone, D. Bull. Am. Meteor. Soc. 95 (Explaining Extreme Events of 2013 from a Climate Perspective special supplement), S11-S15 (2014).

4. http://ca.gov/drought/topstory/top-story-13.html

5. http://www.cpc.ncep.noaa.gov/products/expert_assessment/ season_drought.png

6. NOAA Climate Prediction Center ENSO: Recent Evolution, Current Status and Predictions; available via http://go.nature.com/BCTp44

7. US Department of Defense 2014 Climate Change Adaptation Roadmap; available via http://go.nature.com/XvOrPH 